\title{
Strategies for boosting students' enrolment into business education programme of colleges of education
}

\author{
Clever Omovigho Igberaharha ${ }^{1}$, Moses Onyesom ${ }^{2}$ \\ ${ }^{1}$ Department of Business Education, Faculty of Education, Delta State University, Abraka, Nigeria \\ ${ }^{2}$ School of Business Studies, Delta State Polytechnic, Ogwashi-Uku, Nigeria
}

\section{Article Info \\ Article history: \\ Received Apr 14, 2021 \\ Revised Jul 15, 2021 \\ Accepted Jul 27, 2021 \\ Keywords: \\ Attracting strategies Business education College of education Delta State \\ Retaining strategies \\ Student's enrolment}

\begin{abstract}
A close observation in recent times has shown a steady decline of students' enrolment into business education programme especially in the colleges of education. The situation is becoming worrisome considering the social implications it has on the education industry. Thus, the study was conducted to determine strategies for boosting students' enrolment into business education programme of colleges of education in Delta State. Design of this research was descriptive survey and 118 business education lecturers in the colleges of education in Delta State participated in the survey. Data were collected with questionnaire. The results of data analysis showed that the respondents agreed that the attracting and retaining strategies considered in the study were necessary frameworks for boosting students' enrolment into business education programme. The test of hypotheses showed that irrespective of the years of work experience of the respondents, their responses did not differ significantly. This indicated that the examined attracting and retaining strategies were critical for boosting students' enrolment. It was concluded that the attracting and retaining strategies determined by the study are effective means of reversing the steady decline of students' enrolment experienced in recent years at the colleges of education in Delta State, Nigeria.
\end{abstract}

This is an open access article under the CC BY-SA license.

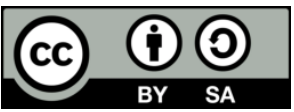

Corresponding Author:

Moses Onyesom

School of Business Studies

Delta State Polytechnic

Ogwashi-Uku, Nigeria

Email: mconyesom@gmail.com

\section{INTRODUCTION}

Every nation of the world aims at equipping and empowering her citizens for gainful living. This is mostly realized through education. Education is the transmission of knowledge, skills, ideas, attitudes and patterns of behavior to a learner [1]. Universally, education as a transformational process is recognized as one of the significant instruments for mitigating poverty and balancing social and economic inequality, as well as the foundation for maintaining sustained growth of the economy. Federal Republic of Nigeria [2] noted that "education is the most important instrument of change." It is fundamental for the construction of democratic, dynamic societies and globally competitive economies. Any person, society or even nation that is knowledgeable is economically powerful. Education, therefore, bestows power on people, societies or nations as it is the tool for human capital development. No nation can achieve meaningful development without human capital development [3]. Education leverages on people's natural talents and abilities to produce a better and progressive society. Education in general encompasses several aspects such as business education. 
Business education as an educational programme is aimed primarily at preparing people for roles in enterprises as employees, entrepreneurs or employers [4]. In the work of one renowned scholar [5], business education was defined as that "broad area of knowledge that deals with a nation's economic system, identifies and explains the rate of business contentment and experiences that prepare individuals for effective participation as citizens, workers, and consumers." Similarly, Onyesom and Okolocha [6] described "business education as the intellectual and vocational preparation of people for earning a living in the contemporary industrial and business environment." Business education is a vocational programme that is skill-oriented and equips its graduates with saleable skills for productive engagements and service delivery. It exposes its recipients to the theories, fundamentals and processes of business.

In the tertiary education system of Nigeria, business education is a discipline or academic course run in the universities under the faculty of education as well as in the colleges of education. "Business education, either in the university or college of education affords its recipients teaching mastery in business subjects, necessary competencies in professional education, functional general education for life, skills to undertake research and additional learning experiences through in-service programmes" [6]. In Nigeria educational landscape, college of education is a higher institution attended after secondary education qualification and it is particularly designed to train teachers for the teaching profession. It provides training and prepares intending teachers at the intermediate level and her graduates are awarded with the Nigerian Certificate in Education (NCE) in theories of instruction, teaching methodology and curriculum delivery. Beside the professional and general education background, colleges of education also train their students in a specific academic field or course such as home economics, mathematics, fine art, chemistry or business education amongst others. Thus, Federal Republic of Nigeria through its policy document known as the "National Policy on Education" postulates that the least entry benchmark qualification for teachers aspiring to join the teaching profession is the Nigerian Certificate in Education (NCE).

Business education as an academic discipline in the Nigerian college of education system is structured to accomplish the objectives as encapsulated by its government regulatory agency called the National Commission for Colleges of Education [7]: 1) To produce well qualified and competent NCE graduates in business subjects who will be able to teach business subjects in the secondary schools and other related educational institutions; 2) To produce NCE business teachers who will be able to inculcate the vocational aspects of business education into the society; 3) To produce NCE business teachers who will be involved in the much desired revolution of vocational development right from primary and secondary schools; 4) To equip students with necessary competencies so as to qualify them for a post-NCE degree programme in business education; 5) To equip graduates with the right skills that will enable them to engage in a life of work in the office as well as for self-employment.

With these objectives, the programme of business education at the level of college of education is structured to train qualified and competent teaching staff that will teach pre-vocational business studies subjects at the basic and secondary schools. Before recent times, business education programme has maintained a steady progressive student's enrolment pattern [8], [9] and its graduates have had a productive career endeavor. This career success is indicative of the students' choice of the programme over the years [10]. However, in spite of its importance in the education industry and society at large, business education as a programme of study at the colleges of education is faced with enormous challenges which stifle the realization of its objectives. The basic of these challenges is the declining rate of students' enrollment into the programme [11], [12]. As observed in previous papers [13]-[15], vocational business education programme is bedeviled with low enrolment of students as a result of public misunderstanding of the benefits, scope and contents of the programme. Considering the soaring rate of unemployment of graduates, parents and students have shown intense inclination for professional educational programmes (like medicine, pharmacy, information technology, vocational art, law) that will enable graduates to be self-engaged rather than seeking for non-existing paid employment [16]. This situation has changed enrolment pattern and students' choices across many disciplines at the expense of courses in humanities and social sciences. Most recently, business education as a programme of study especially at the tier of college of education has experienced a significant steady decline of students' enrolment and the circumstance has progressed from serious to critical. Table 1 shows the disturbing trend of students' rate of enrolment into business education programme of study at the different colleges of education in Delta State in a recent period of five years.

Table 1 shows that urgent and concerted actions are needed to be taken to enhance the rate of students' enrolment because the core existence of business education as a field of study at the college level (intermediate teachers' college) is at the risk of extinction. Focusing on increasing enrolment of students demands comprehensively coordinated initiatives and perhaps new approaches to programmes undertaken in schools [17]-[20]. Koch, et al. [21] suggested a perspective that could provide a roadmap for institutions seeking to improve students' enrolment. The perspective is depicted in the model shown in Figure 1. 
Table 1. Status of enrolment into business education programme (2015-2019)

\begin{tabular}{|c|c|c|c|c|c|}
\hline \multirow{2}{*}{ Colleges } & \multicolumn{5}{|c|}{ Academic Years } \\
\hline & 2015 & 2016 & 2017 & 2018 & 2019 \\
\hline Federal College of Education (Technical), Asaba & 315 & 220 & 162 & 145 & 78 \\
\hline College of Education, Agbor & 184 & 123 & 76 & 54 & 48 \\
\hline College of Education, Warri & 216 & 164 & 87 & 71 & 56 \\
\hline College of Education, Mosogar & 105 & 93 & 76 & 58 & 44 \\
\hline
\end{tabular}

Source: Data obtained from the admission offices of the colleges

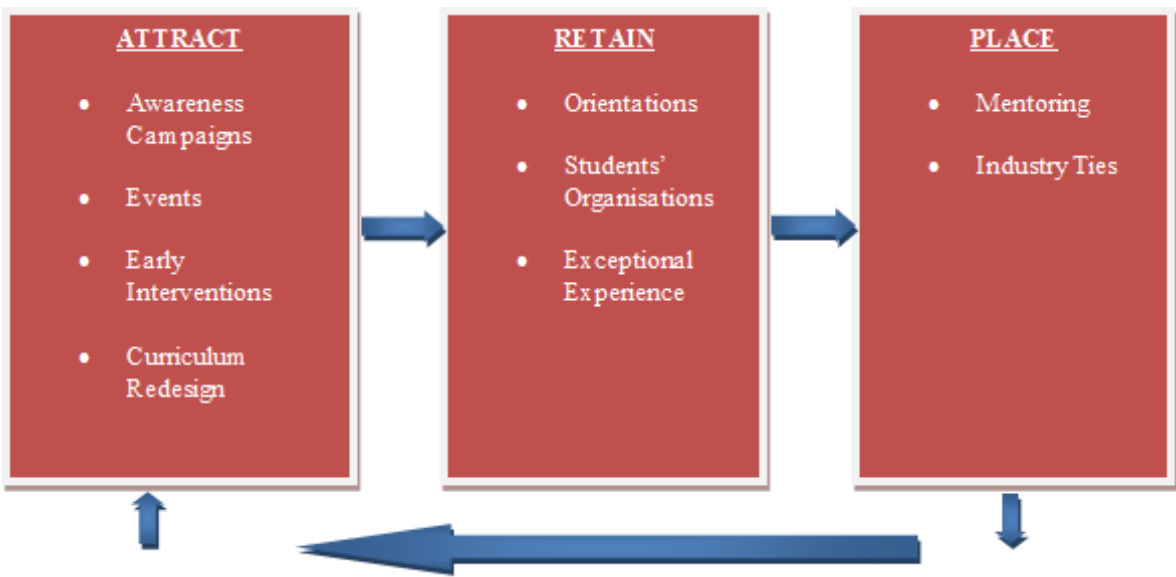

Figure 1. A model approach to students' enrolment

The Model depicted in Figure 1 suggests that business education programme can address the poor students' enrolment challenge by adopting a comprehensive programme perspective as shown above. The perspective in the model goes beyond usual strategies and suggests that educational programmes could introduce "initiatives to attract, retain, and place students" [22]. As recorded in prior submissions [21], [23], the approach develops an affirmative cycle that turns successful business education graduates to fulfilled customers whose attestations and recommendations will endear more prospective students to the programme. Attracting prospective students requires awareness campaigns, events hosting, early interventions and curriculum redesign.

Awareness campaign entails purposive communication to the public about the role of business education in the society; debunking the misconceptions surrounding business education as a programme; highlighting the abundant job opportunities and progression for business education graduates. The awareness campaign could be communicated using but not limited to bumper stickers with inscriptions such as "business education is education for and about business, business education is our business" among others. Awareness campaigns are to stress the innovative roles of business education in creating new jobs and redefining trade, emphasizing why individuals require training in business education, and to portray how business entrepreneurs are leveraging on the knowledge gained from business education to create value and establish successful new enterprises. Furthermore, awareness campaign stimulates interest and creates motivation for business education among young secondary school leavers, parents and stakeholders in general. This is similar to a scholar's view [24] that enrolment mobilization initiatives should focus on students, and parents' interest.

The most critical point to convey in awareness campaigns should be the endearing job prospects awaiting business education graduates. To support these awareness campaigns, [21], [25], [26] noted that educational programmes like business education seeking improved student's enrolment should have "updated recruiting materials, developed Facebook groups, embraced Twitter, designed t-shirts, and have days when students and staff wear the t-shirts." In addition, business education programme can engage in awareness systematically by designing promotional bill boards and posters, displaying highlights about business education programme in corporate media outfits, hosting business education summits, educating advisors, guidance counselors and parents about business education and participating in school events. To improve recognition and awareness about business education programme among students of secondary school category, schools of business education need to execute early intervention strategies [27]. Business education staff and authorities should attend secondary school fairs and provide talks on the programme, offer admission tips and encourage campus visit by the students. They can also host secondary school business education days. 
However, attracted students should be retained in the programme. The retention strategies as suggested by authorities [22], [28] may include organizing business education orientations, setting up effective and engaging student societies and offering business education students with special opportunities. Realizing that current business education students are the foot soldiers that can boost the rate of prospective students into the programme through their "one-to-one marketing", schools of business education should institute various programmes and initiatives to improve current business education students' learning experiences. Accordingly, these programmes and initiatives could focus on building a community of business education students that reinforces, that upwardly mobile career path awaits business education students [29]. Retaining students in the programme could also involve providing exceptional experiences for the students such as competitive engagements, field trips, international visits, leadership roles, providing mentorship which involves instructive relationship/interaction between students and lecturers/industry for effective growth and advancement. Offering accelerated adjustment for students is also a retaining initiative. Added to awareness creation, early intervention programmes, and retaining strategies [30], [31] recommended that academic institutions and/or programmes could contemplate revising its curriculum to be more adaptive to current realities and trends. It should be redesigned in such a way that it adds value to the programme.

Olsen [32] asserted that "every academic administrator knows that it is important to increase student's enrolment, but it is much harder to know how to increase such enrolment." The existence of every institution of learning is a function of students' intake. Thus, students are the very soul of institutions of learning. Colleges of education in Nigeria have struggled to cope with the changing enrolment landscape [33] and many have not been able to adapt. The consequences of ignoring a steady decline of students' enrolment are severe indeed. It ranges from loss of revenue for the school, closure of the programme, to termination of staff employment [34]. From the enrolment trend in colleges of education in Delta State in particular for the past five years, they have not been able to meet $30 \%$ of their admission target in business education programme (Table 1). The danger is that, in no distant time, there will be shortage of NCE graduates (trained prospective teachers) that will teach business subjects at the basic and secondary schools' system. This calls for a great concern as the colleges are in dire situation. The researchers are therefore worried that if effective measures are not evolved to reverse the shape downward curve of students' enrolment, business education programme in colleges of education may face extinction and consequently create total dearth of NCE teachers.

Related previous descriptive survey study [15] designed to determine strategies for improving students' enrolment into vocational technical education programmes of universities in South Eastern Nigeria, raised four research questions and tested four null hypotheses using t-test. Data for the study was gathered with questionnaire and 370 university lecturers in vocational technical education participated in the study. The study found guidance strategies, parental strategies, governmental and non-governmental strategies for improving enrolment into vocational and technical education programmes of universities in the South Eastern Nigeria. In another related previous study [35] which was conducted for improvement of rate of student's enrolment into technical and vocational education programme in Ebonyi State, found that negative attitude of the society towards the programme, poor public perception of the programme and government indifference adversely affect student's enrolment into technical and vocational education programme. However, the study also identified eight strategies for improving enrolment into technical colleges in Ebonyi. Similarly, another prior study [36] focused on investigating strategies for enhancing student's enrolment in home economics education in tertiary institutions in Edo State. It was a descriptive survey research and data generation was through questionnaire. Findings revealed by the study show that poor funding of the programme, parents' negative attitude towards home economics and ignorance of the relevance of the programme were factors responsible for the dwindling state of enrolment in home economics. The study also found that increased funding of home economics programme, properly equipping of home economics laboratories and libraries, increased awareness of the programme and exposing home economics students to longer time for industrial attachment could revamp enrolment of students into the programme.

From available literature, it is evidenced that some research studies have carried out on strategies for increasing enrolment of students especially in vocational technical education and science related areas, but none has addressed business education programme at the college of education level in Delta State. This is the novelty of the current research. In addition, the study focused on attracting and retaining strategies for enhancing students' enrolment. Therefore, this study was designed to determine the strategies for boosting students' enrolment in business education programme of colleges of education in Delta State. In specifics, the study was undertaken to determine: 1) The attracting strategies for boosting student enrolment in business education programme of colleges of education; 2) Retaining strategies for boosting student enrolment in business education programme of colleges of education.

The research questions were posed to provide guideline the for study: 1) What are the attracting strategies for boosting student enrolment in business education programme of colleges of education? 2) What 
are the retaining strategies for boosting student enrolment in business education programme of colleges of education? The null hypotheses were tested in the study: 1) Lecturers of business education will not differ strongly in their mean responses on attracting strategies for boosting student enrolment in business education programme of colleges of education based on their years of work experience; 2) Lecturers of business education will not differ strongly in their mean responses on the retaining strategies for boosting student enrolment in business education programme of colleges of education based on their years of work experience.

\section{RESEARCH METHOD}

\subsection{Research design}

The research design used for this study was the descriptive survey and it was conducted in Delta State using colleges of education. Descriptive survey was succinctly defined [37] as "any procedure in which data are systematically collected from a population or sample thereof through some form of direct solicitation like interview or questionnaire." They added that the data are about the opinions, perceptions, views or feelings of individuals in the population. Other related studies [15], [33], [35], [36], [38] also adopted the descriptive survey as it was found to be the most applicable research design.

\subsection{Population}

The population of the study comprised 118 business education lecturers in Federal College of Education (Technical), Asaba and Colleges of Education in Agbor, Warri, and Mosogar, all in Delta State of Nigeria. No sample was drawn as the entire population participated in the study. This is as a result of the manageable size of the population. The lecturers have different years or lengths of work experiences and they are all experts in the field.

\subsection{Instrumentation}

The instrument for data generation was a questionnaire designed by the researchers with insight gained from literature review. The questionnaire was sub-structured into two major sections. The first section generated respondents' demographic data while the second section contained 27 items bordering on the research questions, formatted on a "four-point rating scale of Strongly Agree (SA), Agree (A), Disagree (D) and Strongly Disagree (SD)." Three professional experts conducted the questionnaire's validity in terms of clarity of language, suitability of items and content coverage. Their inputs were considered in preparing the used copy of the questionnaire. The reliability of the questionnaire was established through test re-test using 10 lecturers in business education at the colleges of education located at Igueben and Ekiadolor, both in Edo State, which is aside the coverage area of the study. The data generated thereof were subjected to Pearson Product Moment correlation analysis and a coefficient of 0.81 was obtained. This coefficient value is indicative of high reliability. The entire respondents to the study (118) were served with a copy of the questionnaire to fill and thereafter 109 copies (92\%) were successfully collected and used for data analysis.

\subsection{Method of data analysis}

The data gathered for the study were analyzed statistically with mean and standard deviation in order to answer the research questions while the null hypotheses were tested at 0.05 level of significance using ANOVA. Decision on the research questions was based on a benchmark mean of 2.50. This implies that "any item with a mean value of 2.50 and above was regarded as agreed while any item with mean value of less than 2.50 was regarded as disagreed". Furthermore, null hypothesis was accepted where the P-value is greater than the 0.05 alpha level and rejected where the P-value is less than the 0.05 alpha level.

\section{RESULTS}

The results presented in Table 2 and Table 3 answered research questions 1 and 2 respectively, while Table 4 and Table 5 show the results of hypotheses 1 and 2 respectively. Table 2 presents the results of respondents' ratings on the attracting strategies for boosting students' enrolment in business education programme. The results indicated that all the items were rated above the mean benchmark point of 2.50. Thus, it implies that all the 17 were rated by the respondents as attracting strategies for boosting students' enrolment in business education programme. This is also confirmed by the grand mean which is above 2.50. The closeness of the standard deviation indicates the homogeneity of respondents' ratings.

Table 3 shows the respondents' ratings on the retaining strategies for boosting students' enrolment in business education programme. The results indicated that all the items were rated above the mean benchmark point of 2.50. Thus, it implies that all the 10 items listed on Table 3 were rated by the respondents 
as retaining strategies for boosting students' enrolment in business education programme. This is also informed by the grand mean which is above 2.50 . The proximity of the standard deviation values indicates the relatedness of respondents' ratings.

Table 2. Mean scores and standard deviation of respondents on attracting strategies

\begin{tabular}{clccc}
\hline S/N & \multicolumn{1}{c}{ Attracting strategies } & Mean & SD & Remarks \\
\hline 1 & Conducting awareness campaigns & 2.93 & 0.55 & Agree \\
2 & Debunking myths about business education & 3.16 & 0.87 & Agree \\
3 & Highlighting job prospects of business education & 3.11 & 1.05 & Agree \\
4 & Use of customized business education stickers & 2.74 & 1.18 & Agree \\
5 & Use of customized business education t-shirts & 3.47 & 0.93 & Agree \\
6 & Creating Facebook groups & 3.88 & 1.10 & Agree \\
7 & Embracing twitter and other relevant social media & 3.24 & 1.17 & Agree \\
8 & Designing promotional posters & 3.50 & 1.28 & Agree \\
9 & Featuring business education talks on media & 3.22 & 1.07 & Agree \\
10 & Creating interactive website for business education & 3.05 & 0.84 & Agree \\
11 & Hosting events to showcase business education & 3.12 & 0.93 & Agree \\
12 & Placing adverts on public and campus buses & 2.73 & 0.79 & Agree \\
13 & Early intervention programmes in basic schools & 2.87 & 1.03 & Agree \\
14 & Visiting secondary schools with business education talks & 3.59 & 0.61 & Agree \\
15 & Organizing business education fairs & 2.84 & 1.25 & Agree \\
16 & Networking with parents, counselors and advisors & 2.87 & 0.71 & Agree \\
17 & Redesigning curriculum with flexible courses and values & 3.48 & 1.57 & Agree \\
& Grand mean & 3.16 & & Agree \\
\hline
\end{tabular}

Table 3. Mean scores and standard deviation of respondents on retaining strategies

\begin{tabular}{clccc}
\hline S/N & \multicolumn{1}{c}{ Retaining strategies } & Mean & SD & Remarks \\
\hline 1 & Instituting regular orientations for students & 3.33 & 1.15 & Agree \\
2 & Cultivating active students' organizations & 3.24 & 0.87 & Agree \\
3 & Providing students with special opportunities & 2.57 & 1.05 & Agree \\
4 & Managing students' expectations & 3.46 & 1.18 & Agree \\
5 & Strengthening students' motivation and commitment & 3.88 & 0.93 & Agree \\
6 & Maintaining efficient communication & 3.91 & 1.10 & Agree \\
7 & Instituting regular interactions with industrial experts & 3.61 & 0.67 & Agree \\
8 & Sponsoring professional development activities & 2.78 & 0.55 & Agree \\
9 & Providing mentorship programmes & 3.54 & 1.01 & Agree \\
10 & Harnessing students' motivation & 3.10 & 0.64 & Agree \\
& Grand mean & 3.34 & & Agree \\
\hline
\end{tabular}

\subsection{Test of hypotheses}

Null hypotheses one and two formulated for the study were tested at 0.05 level of significance using analysis of variance (ANOVA) and their results are presented on Table 4 and Table 5. Table 4 indicates that at 0.05 level of significance, 3 degrees of freedom numerator and 108 degrees of freedom denominator, the Fcalculated value was 1.247 with a P-value of .280 which is greater than 0.05 . Thus, the null hypothesis was therefore accepted. This implies that respondents did not differ strongly in the mean scores on the attracting strategies for boosting student enrolment in business education programme of colleges of education in Delta State based on their years of work experience.

Table 5 indicates that at 0.05 level of significance, 3 degrees of freedom numerator and 108 degrees of freedom denominator, the F-calculated value was 1.487 with a P-value of .361 which is greater than 0.05. Thus, the null Hypothesis was therefore accepted. This implies that respondents did not differ strongly in the mean scores on the retaining strategies for boosting student enrolment in business education programme of colleges of education in Delta State based on their years of work experience.

Table 4. ANOVA of respondents' mean scores on attracting strategies

\begin{tabular}{ccccccc}
\hline Source of variation & SS & Df & MS & F & Sig. & Decision \\
\hline Between groups & 577.578 & 3 & 209.194 & 1.247 & .280 & Not \\
Within groups & 476.457 & 105 & 170.320 & & & Significant \\
Total & 1054.035 & 108 & & & & \\
\hline
\end{tabular}


Table 5. ANOVA of respondents' mean scores on retaining strategies

\begin{tabular}{ccccccc}
\hline Source of variation & SS & Df & MS & F & Sig. & Decision \\
\hline Between groups & 746.583 & 3 & 209.194 & 1.487 & .361 & Not \\
Within groups & 34857.713 & 105 & 170.320 & & & Significant \\
Total & 35604.296 & 108 & & & & \\
\hline
\end{tabular}

\section{DISCUSSION}

The result of the data analysis presented on Table 2 with regards to research question one revealed that attracting strategies are crucial initiatives needed to boost students' enrolment in business education programme of colleges of education in Delta State. This finding conforms to prior studies [21], [39], [40] which found that awareness through the social media, posters, conventional media outlets and organizing fairs are approaches for projecting a programme to prospective students and thus increasing student enrolment in that programme. Business education needs to embrace these strategies such as coordinated awareness campaigns, engage in early interventions in basic and secondary schools to get school leavers familiarized with business education programme and organize social events that will project business education programme.

The attracting strategies examined in the study are potent measures with which business education programme of colleges of education in Delta State can use to curtail the declining tide of student enrolment. When awareness for a programme is created and directed to the appropriate audience, it can stimulate interest and attract students into the programme. Accordingly, other former studies [14], [33], [41] found that public enlightenment (a tool for awareness) is an effective strategy for attracting students to technical and vocational education. An increasing decline of student enrolment in any educational programme calls for concerted efforts particularly from the administrators of the programme [12], [42], [43]. Therefore, attracting strategies must be focused, calculated and purpose driven in order to achieve the target goals. Any designed strategy for attracting students into business education programme should first identify the prospective students and determine access to reach them. Business education programme teaches skills and competencies for personal use as an entrepreneur, corporate employee, business executive as well as a business teacher. Therefore, students need to be attracted and engaged in this all-encompassing programme for the benefit of the society.

The test of null hypothesis one shows that irrespective of the years of work experience of the respondents, their responses did not differ strongly on the attracting strategies for boosting students' enrolment in business education programme of colleges of education in Delta State. This is indicative that attracting strategies are critical approaches that could be explored and deployed by managements and authorities of business education programme in the colleges of education to increase the enrolment of prospective students into the programme. This result conforms to a study [44] which revealed that teachers' length of experience did not strongly influence their opinions on the determinants of students' enrolment into technical vocational education programme.

The results of the study shown on Table 3 regarding research question two indicated that all the retaining strategies examined in this study were important for boosting students' enrolment into business education programme. This finding agrees results of earlier studies [45]-[47] which found that strategic students' retention programmes and policies reduce enrolment declines. The result of the current study shows that respondents by their ratings agreed that the retaining strategies could boost students' enrolment in business education. Students attracted to any given programme need to be retained [48]. Applying retaining strategies will reduce the rate of students' attrition from any given programme. Retaining strategies determined by this study include regular orientation for the students, engaging them in exceptional experiences, strengthening students' motivation and commitment, providing mentorship programmes, sponsoring professional development activities, instituting regular interactions with industrial experts, maintaining efficient communication. Thus, recent studies [49]-[51] had strongly submitted that occupational awareness and career guidance are potent factors for creating student's interest and fostering enrolment rate into any programme of learning. Additionally, other studies [33], [35] identified scholarship, excursion, adequate learning facilities and infrastructure, hands-on engagements, sporting and recreational activities as strategies for retaining secondary school students in technical and vocational education programme. All of these strategies will retain students in the programme and keep the student's base from declining.

Again, the test of null hypothesis two indicated that despite the variations in the years of work experiences of the respondents, no strong difference was found on their responses regarding the retaining strategies for boosting students' enrolment into business education. This implies that retaining strategies are also critical approaches that if properly harnessed by managements of business education programme in the colleges of education could help sustain students' strength from plummeting [52] and enhance the enrolment of prospective students into the programme. 


\section{CONCLUSION}

From the findings of this study, it could be concluded that the attracting and retaining strategies determined by this study are effective means of reversing the steady decline of students' enrolment experienced in recent years at the colleges of education in Delta State. Therefore, colleges of education in Delta State should urgently adopt the attracting and retaining strategies examined in this study to enhance student's enrolment into business education programme. Furthermore, the following recommendations were made: Authorities of business education programme should embark on coordinated and focused awareness campaigns; Public enlightenment should be carried out regularly to sensitize the public about the prospects of business education programme; Students should be engaged in exceptional experiences and activities that would strengthen their motivation and commitment; Authorities of business education programme should build efficient communication flow with students; Professional mentorship programmes should also be provided for the students to enhance their interest and adjustment.

\section{REFERENCES}

[1] I. Odoemenam, "Achieving the aims of lifelong education through effective implementation of general studies NCCE curriculum in Nigerian colleges of education," In E.U. Okolie, Ed., Education in the Information Age: Global Challenges and Enhancement Strategies. Nsukka: University Trust Publishers, 2008, pp. 213-224.

[2] Federal Republic of Nigeria, National Policy on Education, 6th Ed. Lagos: NERDC Press, 2013.

[3] C. O. Nwajinka, and N. I. Odogo, "Educational reform in Nigeria: The challenges of technical/vocational education," In E.U. Okolie, Ed., Education in the Information Age: Global Challenges and Enhancement Strategies. Nsukka: University Trust Publishers, 2008, pp. 99-106.

[4] E. A. C. Etonyeaku, "Office operational skills perceived as necessary for office information systems by secretaries in University of Nigeria, Nsukka," Business Education Journal, vol. 7, no. 2, pp. 131-139, 2010.

[5] E. C. Osuala, Foundations of vocational education. Enugu: Cheston Agency Limited, 2004.

[6] M. Onyesom, and C. C. Okolocha, "Assessment of the adequacy of instructional resources in business education programmes relative to NCCE standards in colleges of education in Nigeria," Journal of Education and Learning, vol. 2, no.2, pp. 165-178, 2013, doi: 10.5539/jel.v2n2p165.

[7] National Commission for Colleges of Education, Nigeria certificate in education minimum standards for vocational and technical education. Federal Republic of Nigeria, National Commission for Colleges of Education, 2012.

[8] P. U. Osadebe, and J. F. Osadebe, "Undergraduate business education students' perception on information and communication technology use in teaching and learning," International Journal of Evaluation and Research in Education (IJERE), vol. 9, no. 2, pp. 359-363, 2020, doi: 10.11591/ijere.v9i2.20326.

[9] H. O. Etaga, C. N. Etaga, K. F. Aforka, and S. E. Okeke, "Student enrolment pattern in Anambra State (20012015)," African Journal of Mathematics and Statistics Studies, vol. 3, no.4, pp. 62-71, 2020.

[10] M. R. Siddiky and S. Akter, "The students' career choice and job preparedness strategies: A social environmental perceptive," International Journal of Evaluation and Research in Education (IJERE), vol. 10, no. 2, pp. 421-431, 2021, doi: 10.11591/ijere.v10i2.21086.

[11] C. U. Umezuruike, "Factors responsible for low students' enrolment in science in senior secondary schools: Challenges of the $21^{\text {st }}$ century," Multidisciplinary Journal of Research Development, vol. 10, no. 2, 2008. [Online]. Available: https://www.globalacademicgroup.com/journals/knowledge\%20review/Umezuruike.pdf.

[12] S. S. Masood, "How to control a decrease in physics enrolment?" Cornell University, 2014. [Online]. Available: https://arxiv.org/abs/1405.6442v1.

[13] V. I. Igbinedion and I. J. Ojeaga, "Use of career education and occupation information services in boosting enrolment into vocational and technical education programs in Nigeria," International Education Studies, vol. 5, no.4, pp. 229-236, 2012, doi: 10.5539/ies.v5n4p229.

[14] P. C. Okwelle and V. I. A. Agwi, "Strategies for improving female students' enrolment in technical and vocational education programmes through public relations activities in Nigeria," International Journal of Advanced Academic Research: Arts, Humanities and Education, vol. 4, no. 1, pp. 1-13, 2018.

[15] M. Onwumere and M. N. Modebelu, 'Strategies for improving students' enrolment into vocational technical education programmes of universities in South East Nigeria," Vocational and Technical Education Journal, vol. 2, no.2, pp. 58-68, 2020.

[16] M. K. Omar, Md A. Rauf, N. Ismail, A. Mat Rashid, H. Mohd Puad, and A. Zakaria "Factors on deciding TVET for first choice educational journey among pre-secondary school students," European Journal of molecular and Clinical Medicine, vol. 7, no. 3, pp. 609-627, 2020.

[17] The Chalk Team, "The secret to increasing private school enrolment," Chalk.com Education Inc., 2019. [Online]. Available: https://www.chalk.com/resources/increase-private-school-enrollment.

[18] G. Fretwell, Develop a data-driven enrolment programme to increase enrolment through improved recruitment and retention initiatives. Tulsa: Noel-Lavitz, 2010. [Online]. Available: https://docplayer.net/2178077-revisedimplementation-plan-develop-a-data-driven-enrollment-program-to-increase-enrollment-through-improvedrecruitment-and-retention-initiatives.html.

[19] B. M. Agboola and J. K. Adeyemi, "Projecting enrolment for effective academic staff planning in Nigerian universities," Educational Planning, vol. 21, no. 1, pp. 5-17, 2013. 
[20] University of West Florida, "Strategic enrolment and student success plan 2018-2022," 2018. [Online]. Available: https://uwf.edu.

[21] H. Koch, C. V. Slyke, R. Watson, J. Well, and R. Wilson, "Best practices for increasing IS enrolment: A program perspective," Communications of the Association for Information Systems, vol. 26, no. 22, pp. 477-492, 2010, doi: 10.17705/1CAIS.02622.

[22] P. Y. Talbert, "Strategies to increase enrolment, retention and graduation rates," Journal of Developmental Education, vol. 36, no.1, pp. 22-36, 2012. [Online]. Available: https://eric.ed.gov/?id=EJ1035683.

[23] M. Ramchander, and M. Naude, "The relationship between increasing enrolment and student academic achievement in higher education," African Education Review, vol. 15, no. 4, pp. 1-17, 2018, doi: 10.1080/18146627.2017.1340804.

[24] I. E. Chukwuka and N. G. Nma, "Mobilization initiatives for enhancing secondary school students' enrolment into vocational and technical education program of universities for self reliance in South East Nigeria," Agricultural Science, vol. 6, no. 7, pp. 623-629, 2015, doi: 10.4236/as.2015.67061.

[25] C. C. Uchendu, I. A. Nwafor and M. G. Nwaneri, "Marketing strategies and students' enrolment in private secondary schools in Calabar Municipality, Cross Rivers State, Nigeria," International Journal of Education and Practice, vol. 3, no. 5, pp. 212-223, 2015, doi: 10.18488/journal.61/2015.3.5./61.5.212.223.

[26] M. A. Tukur, L. A. Abubakar, A. S. Omosidi, and O. C. Ijeoma, "Marketing mix and students' enrolment in private universities in Kwara State, Nigeria," Makerere Journal of Higher Education, vol. 10, no. 2, pp. 53-63, 2019, doi: 10.4314/majohe.v10i2.5.

[27] M. Kiser and E. E. Hammer, "Need to increase enrolment: A successful academic provisionary program," Journal of College Student Retention: Research, Theory \& Practice, vol. 18, no. 2, pp. 217-233, 2015, doi: $10.1177 / 1521025115584749$.

[28] J. I. Oviawe, "Sustaining students' interest in prevocational education: A strategy for fostering enrolment into technical colleges in Nigeria," International Journal of Academic Research in Progressive Education and Development, vol. 4, no. 3, pp. 1-11, 2015.

[29] C. Johnson and C. King, "Getting to and through college: Effective strategies to improve college enrolment and completion rates in Texas," Texas Family Impact Seminars, University of Texas, 2011.

[30] W. Watera, "Improving female students' enrolment in STEM demands policies that align the social and technical aspects of the problem," 2018. [Online]. Available: https://www.kas.de/documents/280229/4671449/Y4P+ Policy+Papers+Winnie+Watera.pdf/adc02521-1ea4-e6f0-149e-34de43f911de?version=1.0\&t=1549011243338

[31] J. J. Hayes, "Increasing enrolment: Evaluating college-choice factors at a Midwest Christian University," Doctoral Dissertation, Olivet Nazarene University, 2014. [Online]. Available: https://digitalcommons.olivet.edu/edd_diss/70.

[32] A. Olsen, "Six proven ways to boost your college enrolment," EAB, 2018. [Online]. Available: https://eab.com/insights/blogs/enrollment/6-proven-ways-to-boost-your-college-enrollment.

[33] J. I. Ofulue, "Strategies for attracting and retaining vocational and technical education teachers in Delta State secondary schools," Unpublished Master Thesis, Ebonyi State University, Abakaliki, 2018.

[34] L. McBride, N. Vaduganathan, J. Puckett, N. Rimmer, and T. Henry Adapting to enrolment declines in urban school systems: Managing costs while improving educational quality. Boston: The Boston Consulting Group, 2013.

[35] E. E. Inyiagu, "Strategies for improving students' enrolment into technical college programmes in Ebonye State," Journal of Educational Policy and Entrepreneurial Research, vol. 2, no. 5, pp. 101-107, 2015. [Online]. Available: http://jeper.org/index.php/JEPER/article/view/124.

[36] B. E. Uwameiye, "Strategies for enhancing student enrolment in home economics education in tertiary institutions in Edo State," International Journal of Economics and Financial Research, vol. 1, no. 8, pp. 106-112, 2015. [Online]. Available: https://ideas.repec.org/a/arp/ijefrr/2015p106-112.html.

[37] T. Mathiyazhagan, and D. Nandan, "Survey design method," Media Mimansa, pp. 34-83, 2010.

[38] J. K. Aina, and M. O. Ayodele, "The decline in science students' enrolment in Nigerian colleges of education: Causes and remedies," International Journal of Education and Practice, vol. 6, no. 4, pp. 167-178, 2018, doi: 10.18488/journal.61.2018.64.167.178

[39] O. K. A. Nnadozie, "Causes and solutions to low male enrolment in agricultural education in Nigeria: Experience of Institute of Ecumenical Thinkers' Corner, Enugu (IECE)," International Journal of Education, vol. 2, no. 2, pp. 45-60, 2017.

[40] M. Joshi, "Increase Student Enrollment with these 10 practical tips," Leadsquared, 2018. [Online]. Available: https://www.leadsquared.com/how-to-increase-student-enrollment.

[41] S. T. Puyate, "Strategies for improving female students' enrolment in technical-vocational education and training (TVET) programmes in Rivers and Bayelsa States," Journal of Education in Developing Areas, vol. 25, no. 1, pp. 65-74, 2017.

[42] M. O. Ode, A. A. Babayeju, and M.A. Obalowu, "Low students' enrolment in home economics programme: A case of University of Ilorin," Research on Humanities and Social Sciences, vol. 3, no. 14, pp. 46-53, 2013. [Online]. Available: https://www.iiste.org/Journals/index.php/RHSS/article/view/7926.

[43] I. A. Matthew and A. Israel, "Factors influencing dropout of students as perceived by principals of public secondary schools in central senatorial district of Ondo State, Nigeria," International Academic Journal of Education and Literature, vol. 2, no.1, pp. 135-148, 2021, doi: 10.47310/iajel.2021.v02i01.012.

[44] O. J. Abiodun-Oyebanji and S. M. Ojetunde, "Determinants of students' enrolment in technical and vocational education in Ondo State, Nigeria," Kenya Journal of Educational Planning, Economics and Management, vol. 10, no. 1, pp. 1-10, 2016. 
[45] E. O. Ademola, A. T. Ogundipe, and W. T. Bbatunde, "Students' enrolment into tertiary institutions in Nigeria: The influence of the founder's reputation - A case study," Computing, Information Systems, Development Informatics \& Allied Research Journal, vol. 5, no. 3, pp. 55-82, 2014.

[46] M. P. Kagwiria, "Factors influencing students' enrolment in agricultural subject in public secondary schools in Kiambu East District, Kiambu County, Kenya," Master Thesis, The Catholic University of Eastern Africa, Kenya, 2013.

[47] A. Elzawawy, H. Rahemi, Y. Budhoo, S. He, and M. Ducharme "Increasing student enrolment and achievement in emerging and engineering technology," Paper presented during the 2018 American Society for Engineering Education Annual Conference and Exposition, June 24-27, The Salt Palace Convention Center, Salt Lake City, UT, 2018.

[48] S. Chen, "College costs, freshman enrolment and student quality: Evidence from an Urban State University," International Journal of Information and Education Technology, vol. 6, no. 9, pp. 664-671, 2016, doi: 10.7763/IJIET.2016.v6.771.

[49] J. I. Oviawe, "Fostering students' enrolment in technical education programme through career guidance and occupational awareness," Education Journal, vol. 6, no. 4, pp. 125-132, 2017, doi: 10.11648/j.edu.20170604.11.

[50] I. N. Dokubo and M. T. Deebom, "Gender disparity towards students' enrolment in technical education in Rivers State: Causes, effects and strategies," International Journal of Research - Granthaalayah, vol. 5, no. 10, pp. 1-10, 2017, doi: 10.5281/zenodo.1039567.

[51] E. K. Najoli, "The effectiveness of wited programme on enrolment of women in technical and vocational education and training (TVET)," EURASIA Journal of Mathematics, Science and Technology Education, vol. 15, no. 3, pp. 1-11, 2019, doi: 10.29333/ejmste/103034.

[52] F. Mehboob, S. M. M. Shah, and N. A. Bhutto, "Factors influencing student's enrolment decisions in selection of higher education institutions," Interdisciplinary Journal of Contemporary Research in Business, vol. 4, no. 5, pp. 558-568, 2012. 